\title{
PERAN BANK INDONESIA DALAM KEJAHATAN PERBANKAN YANG DILAKUKAN OLEH BANK BALI
}

\author{
Hamja \\ Universitas Wiralodra, Indramayu \\ Email: hamja.hamja904@unwir.ac.id
}

\begin{abstract}
The existence of a central bank is also needed to regulate and supervise banks so that their activities can develop healthy and run smoothly so that it can encourage economic activities. This is considering that the existence of an impartial regulator will bring banks to carry out their operations efficiently and be able to advance economic development. In the interbank payment system, Bank Indonesia has the duty to regulate and maintain a smooth payment system. Including the problems that occurred in the case of Bank Bali, the task of Bank Indonesia as an institution that regulates and maintains a smooth payment system between BDNI and Bank Bali.
\end{abstract}

\section{Key Word: Central Bank, Breeding Crime, Bank Bali}

\section{PENDAHULUAN}

Dalam Pasal 33 (4) UUD RI Tahun 1945 menyatakan:

"Perekonomian nasional diselenggarakan berdasarkan atas demokrasi ekonomi dengan prinsip kebersamaan, efisiensi berkeadilan, berkelanjutan, berwawasan lingkungan, kemandirian serta menjaga keseimbangan kemajuan dan kesatuan ekonomi nasional."

Rumusan Pasal tersebut memperlihatkan bahwa Indonesia merupakan negara yang sangat peduli akan kesejahtraan masyarakatnya. Oleh karena itu betapa sangat penting keberadaan bank sebagai alat untuk memperlancar transaksi-transaksi bisnis sehingga masyarakat dapat meningkatkan taraf hidupnya. Mengingat betapa pentingnya lembaga perbankan maka pemerintah pada tahun 1992 mengeluarkan suatu peraturan perundangundangan yaitu Undang-Undang Nomor 7 tahun 1992 tentang perbankan sebagai pengganti Undang-Undang nomor 14 tahun 1967 tentang pokok-pokok perbankan yang sudah tidak dapat lagi mengikuti, baik perklembangan perekonomian nasional maupun internasional. ${ }^{1}$

Pada tahun 1998 kita mengalami krisis dibidang perbankan yang sampai saat ini masih dirasakan imbasnya. Dengan adanya krisis tersebut otomatis perekonomian negara Indonesia juga berubah. Dengan berubahnya perekonomian dan berbagai masalah dalam

\footnotetext{
${ }^{1}$ Muhammahd Djumhana, Hukum Perbankan Indonesia, cet 5, PT Citra Aditya Bakti, Bandung, 2006, hlm 27
} 
perekonomian pemerintah melihat bahwa Undang-Undang Nomor 7 tahun 1992 dianggap tidak lengkap, oleh karena itu pemerintah melakukan perubahan dengan melahirkan Undang-Undang Nomor 10 Tahun $1998 .^{2}$

Secara umum krisis terjadi di akibatkan dari lemahnya kualitas corporate governance khususnya dalam pengelolaan perbankan. Liberalisasi sektor perbankan yang berawal sejak tahun 1998 lebih banyak berimplikasi pada peningkatan pada peningkatan kuantitas dari pada kualitas lembaga perbankan, sehingga efisiensi dan stabilitas perbankan masih jauh dari yang di harapkan. Rendahnya kualitas perbankan antara lain tercermin dari lemahnya kondisi internal sector perbankan, terutama sebagai dampak dari konsentrasi kredit yang berlebihan, lemahnya managemen bank, kurangnya transparansi, lemahnya system pembukuan (poor accounting), lemahnya pengendalian intern antara lain mengakibatkan terjadinya pelanggaran batas minimum pemberian kredit (BPMK) serta pemberian pinjaman pada pihak terkait ${ }^{3}$.

Pada tanggal 26 Januari 1998 Terbit Keputusan Presiden Nomor 26 Tahun 1998 tentang jaminan atas kewajiban pembayaran bank umum. Keputusan ini untuk mengatasi krisis kepercayaan terhadap perbankan akibat likuidasi bank pada 1997. Bank Bali mengirim surat ke BPPN perihal tidak terbayarnya tagihan piutang di BDNI dan BUN yang timbul dari transaksi money market, SWAP, dan pembelian promissory notes. Tagihan pada BDNI (belum dihitung bunga) Rp 428,25 miliar dan US\$ 45 juta. Sedangkan tagihan ke BUN senilai Rp 200 miliar. Tetapi BI menyampaikan secara tertulis ke tim pemberesan BDNI tentang penolakan untuk memproses lebih lanjut klaim Bank Bali dengan alasan klaim belum didaftar dan terlambat mengajukan klaim, satu klaim tidak terdaftar, dan satu klaim ditolak karena tidak termasuk dalam jenis kewajiban yang dijamin (transaksi forward-sell) senilai Rp 1,131 miliar.

Penulis tertarik dengan dengan kasus bank Bali ini karena bank adalah sebagai urat nadi perekonomian negara seharusnya, sebelum memberikan kredit maka bank harus menerapkan prinsip kehati-hatian (prudensial banking), sehingga keberlangsungan usaha bank sebagai lembaga intermediasi dapat berjalan dengan lancar.

Berdasarkan uraian latar belakang tersebut, maka dirumuskan permasalahan hukum sebagai berikut: Bagaimanakah Peran Bank Indonesia dalam kejahatan perbankan yang dilakukan oleh bank bali?

\footnotetext{
${ }^{2}$ Ibid , hlm 31

${ }^{3}$ Emmy Yusaharie(ed), Perseroan Terbatas dan Good Corporate Governance, Rangkaian Lokakarya Membahas Masalah-Masalah Kepailitan dan Wawasan hukum Bisnis lainya, Jakarta, 2004, hlm 72
} 


\section{METODE}

Sifat penelitian dalam penulisan ini adalah deskriptif yang dilakukan dengan pendekatan yuridis normatif. Jenis dan sumber data yang digunakan adalah data sekunder. Pengumpulan data dilakukan terutama dengan teknik studi dokumen (library research and online research) dengan menginventarisasi data sekunder yang diperlukan, baik berupa bahan hukum primer, sekunder maupun tersier, kemudian melakukan penelusuran sejarahnya dan sinkronisasi antar bahan hukum tersebut. Bahan hukum primer yang dipergunakan terdiri dari peraturan perundang-undangan terutama yang berkaitan dengan hukum perbankan. Bahan hukum sekunder yang akan digunakan digunakan antara lain berupa: karya ilmiah, hasil penelitian dan literatur yang berkaitan dengan substansi penelitian. Bahan hukum tersier, yaitu bahan-bahan yang menunjang informasi bahan hukum primer dan sekunder, antara lain data dari surat kabar, jurnal, kamus, ensiklopedia.

\section{PEMBAHASAN}

\subsection{Analisis unsur-unsur kejahatan perbankan dalam kasus Bank Bali}

Kronologis kasus bank bali: ${ }^{4}$

1. Terbit pada tanggal 26 Januari 1998 Keputusan Presiden Nomor 26 Tahun 1998 tentang jaminan atas kewajiban pembayaran bank umum. Keputusan ini untuk mengatasi krisis kepercayaan terhadap perbankan akibat likuidasi bank pada 1997.

2. Pada tanggal 8 Maret 1998 Pemerintah mengeluarkan Surat Keputusan Bersama BPPN dan BI, Nomor 1/BPPN/1998 dan Nomor 30 /270/KEP/DIR berisi petunjuk pelaksanaan penjaminan.

3. Pada tanggal 18 Maret 1998 Bank Bali mengirim surat ke BDNI untuk minta konfirmasi soal utang-utangnya yang jatuh tempo pada 2 Maret 1998 sampai 16 Maret 1998 (6 transaksi).

4. 9 Juli 1998 Tim manajemen BDNI melalui suratnya menyatakan, klaim atas kewajiban BDNI ke Bank Bali sudah diajukan ke BPPN.

5. 21 Oktober 1998 Bank Bali kirim surat ke BPPN perihal tidak terbayarnya tagihan piutang di BDNI dan BUN yang timbul dari transaksi money market, SWAP, dan pembelian promissory notes. Tagihan pada BDNI (belum dihitung bunga) Rp 428,25 miliar dan US\$ 45 juta. Sedangkan tagihan ke BUN senilai Rp 200 miliar.

4 “Kronologis skandal bank bali, tempo interaktif, 4 maret 2004 
6. 27 Oktober 1998 BI menyampaikan secara tertulis ke tim pemberesan BDNI tentang penolakan untuk memproses lebih lanjut klaim Bank Bali dengan alasan klaim belum didaftar dan terlambat mengajukan klaim, satu klaim tidak terdaftar, dan satu klaim ditolak karena tidak termasuk dalam jenis kewajiban yang dijamin (transaksi forward-sell) senilai Rp 1,131 miliar.

7. 23 Desember 1998 Bank Bali kembali mengirim surat ke BPPN perihal tagihan piutang ke BDNI dan BUN tidak kunjung berhasil. Bank Bali juga meminta BPPN membantu memecahkan masalah ini.

8. 11 Januari 1999 Bank Bali dan PT Era Giat Prima (EGP) meneken perjanjian pengalihan (cessie) tagihan piutang ke BDNI dan BUN. Jumlah seluruh tagihan piutang Bank Bali Rp 798,09 miliar. Disepakati paling lambat tiga bulan kemudian tagihan itu sudah diserahkan ke Bank Bali. Kemudian, Bank Bali juga menandatangani perjanjian cessie dengan Direktur Utama PT Era Giat Prima Setya Novanto. Bank Bali menjual seluruh tagihan pinjaman antarbanknya di BDNI, BUN, dan Bank Bira ke PT EGP. Total tagihan itu mencapai Rp 3 triliun.

9. 12 Januari 1999 Wakil Ketua BPPN Pande Lubis mengirim surat ke Bank Bali. Isinya, BPPN sedang mengumpulkan dan mempelajari data mengenai transaksi Bank Bali untuk mencari pemecahan masalah.

10. 15 Februari 1999 BPPN meminta bantuan BI untuk melakukan verifikasi atas tagihan Bank Bali ke BDNI dan BUN dari segi kewajaran dan kebenarannya.

11. 16 Februari 1999 BI tolak usulan Pande Lubis untuk meneliti kembali klaim Bank Bali karena sebelumnya BI sudah menyatakan secara administrasi tidak berhak.

12. 18 Februari 1999 Pande Lubis mengeluarkan memo kepada Erman Munzir yang berisi usulan untuk memeriksa ulang klaim Bank Bali. Erman kemudian mengaku telah minta Direktur UPMB I memprioritaskan klaim Bank Bali.

13. 22 Maret 1999 BI melakukan verifikasi terhadap tagihan-tagihan Bank Bali ke BDNI dan BUN. Hasilnya, antara lain, tidak ditemukan indikasi ketidakbenaran dan ketidakwajaran transaksi SWAP, forward dan L/C antara Bank Bali dengan BDNI, transaksi pembelian promes yang di-endorse BUN belum sesuai dengan prinsip praktek perbankan yang berhati-hati.

14. 29 Maret 1999 PT EGP memberikan surat kuasa ke Bank Bali untuk dan atas nama PT EGP menagih ke BUN piutang beserta bunganya sebesar Rp 342,919 miliar dan mengkreditkannya ke rekening perusahaan itu. Hal serupa dilakukan terhadap 
penagihan piutang beserta bunganya ke BDNI yang besarnya Rp 1, 277 triliun dan mengkreditkannya ke rekening PT EGP.

15. 1 April 1999 Bank Bali mengirim surat ke BPPN. Isinya ralat tentang jumlah tagihan ke BDNI dan BUN.

16. 9 April 1999 BPPN menolak klaim tagihan Bank Bali terhadap BUN. Pengecualian terhadap BDNI. Meski begitu, harus ada persetujuan dari Bank Indonesia atau Menteri Keuangan.

17. 14 Mei 1999 Revisi Surat Keputusan Bersama Program Penjaminan Pemerintah:

- Keterlambatan administratif bisa diterima selama tagihan valid,

- Pengajuan klaim dapat dilakukan oleh salah satu pihak, baik debitor atau kreditor,

- Ketidakberlakuan penjaminan diperluas sehingga mencakup kewajiban yang berasal dari pihak terkait,

- Dana publik yang berasal dari perusahaan Asuransi dan Dana pensiun dikeluarkan dari kelompok pihak terkait.

18. 11 Juni 1999 BPPN meminta BI melakukan pembayaran dana antarbank BB sebesar Rp 904 miliar. Dana Rp 904 miliar dari BI mengucur ke rekening BB di BI (piutang berikut bunganya).

19. 3 Juni 1999 BPPN instruksikan transfer dana dari rekening Bank Bali di Bank Indonesia ke sejumlah rekening berjumlah Rp 798 miliar secara bersamaan (Rp 404 miliar ke rekening PT EGP di Bank Bali Tower, Rp 274 miliar ke rekening Djoko S. Tjandra di BNI Kuningan, 120 miliar ke rekening PT EGP di BNI Kuningan)

20. 9 Juni 1999 Setelah uang keluar dari BI, janji PT EGP menyerahkan surat-surat berharga pemerintah yang harusnya jatuh tempo pada 12 Juni 1999 malah diubah dalam perjanjian penyelesaian. Isinya, Bank Bali agar memindahbukukan dana sebesar Rp 141 miliar ke PT EGP. Alasannya, tagihan Bank Bali dari BI hanya Rp 798 miliar, sehingga dikurangkan saja dengan uang yang mengalir dari BI sebesar Rp 904 miliar.

21. 20 Juli 1999 Standard Chartered Bank melaporkan hasil due diligence dan menemukan:

a. Terjadi tambahan kerugian akibat pembayaran keluar dari bank sebesar Rp 546 miliar sehubungan dengan klaim antarbank sebesar Rp 905 miliar 
b. Adanya usaha penjualan aset-aset bank oleh manajemen, BPPN menolak untuk menerima kerugian tambahan tersebut sebagai bagian dari rekapitalisasi

22. 23 Juli 1999 Penyerahan Bank Bali dari Bank Indonesia ke BPPN berdasarkan SK Gubernur BI no 1/14/Kep Dpg/1999 menyusul terlampauinya batas waktu pencapaian kesepakatan antara Standard Chartered Bank dan pemegang saham Bank Bali

23. 30 Juli 1999 Ahli hukum perbankan Pradjoto membeberkan jaringan money politics, dalam transaksi penagihan piutang Bank Bali terhadap BDNI, BUN dan Bank Bira senilai Rp 3 triliun, yang melibatkan Setya Novanto (Dirut PT EGP), dengan dugaan adanya dukungan sejumlah pejabat tinggi negara.

24. 5 Agustus 1999BPPN membentuk tim investigasi di bawah pengawasan International Review Committee untuk menginvestigasi kebenaran transaksi cessie, meneliti dasar hukumnya, menelaah proses pengambilan keputusan atas transaksi, melakukan pemeriksaan, penelitian, pengumpulan data, dan penyelidikan terhadap pengalihan dana yang dilakukan Bank Bali ke PT EGP.

25. 27 September 1999Pejabat sementara Jaksa Agung Ismudjoko SH mengungkapkan, tim penyidik Kejaksaan Agung yang dipimpin ketua tim Pengkaji Pidana Khusus Ridwan Mukiat siap menyidik skandal Bank Bali dengan mencoba memanggil orang-orang yang diduga terkait dalam kasus Bank Bali.

26. 7 Oktober 1999 Presiden BJ Habibie telah menyetujui pemeriksaan tiga pejabat tinggi di kabinet waktu itu, salah satunya Gubernur Bank Indonesia Syahril Sabirin, sebagai saksi dalam kasus skandal Bank Bali.

27. 29 November 1999 Kejaksaan Agung menyatakan telah menerima surat izin pemeriksaan Syahril Sabirin. Pemeriksaan Syahril menjadi menarik setelah Wakil Dirut Bank Bali Firman Soetjahja saat diperiksa tim penyidik mengakui adanya pertemuan di Hotel Mulia pada 11 Februari 1999 yang membahas soal cessie.

28. 5 Juni 2000 Gubernur BI Syahril Sabirin resmi jadi tersangka kasus Bank Bali. Dia dipersalahkan tidak menerapkan prinsip kehati-hatian yang merupakan prinsip perbankan.

29. 21 Juni 2000 Syahril Sabirin ditahan di Kejaksaan Agung.

30. 28 Agustus 2000 Majelis hakim Pengadilan Negeri Jakarta Selatan yang diketuai Soedarto membebaskan Joko dari tuntutan hukum. Majelis berpendapat, kasus 
Joko bukan termasuk pidana, melainkan perdata. Sebelumnya, jaksa Antasari Azhar menuntutnya 18 bulan penjara.

31. 28 Juni 2001Mahkamah Agung kembali memenangkan Joko S. Tjandra. Majelis Hakim Agung memperkuat argumentasi majelis hakim Pengadilan Negeri Jakarta Selatan. Namun, satu anggota majelis kasasi, Artidjo Alkostar, mengajukan dissenting opinion dengan menyatakan Joko bersalah melakukan korupsi.

32. 13 Maret 2002 Syahril Sabirin divonis bersalah oleh majelis hakim Pengadilan Negeri Jakarta Pusat dan dihukum tiga tahun penjara.

33. Maret 2002 Mahkamah Agung menolak gugatan EGP di PTUN yang meminta agar surat keputusan mengenai pembatalan pengalihan tagihan Bank Bali ke EGP oleh BPPN dicabut.

34. Agustus 2002 Pengadilan Tinggi DKI Jakarta membebaskan Syahril Sabirin dari semua dakwaan.

35. 12 Juni 2003 Kepala Kejaksaan Negeri Jakarta Selatan mengirim surat kepada direksi Bank Permata agar menyerahkan barang bukti berupa uang Rp 546,4 miliar. Pada hari yang sama, direksi Bank Permata mengirim surat ke BPPN untuk minta petunjuk.

36. 17 Juni 2003 Direksi Bank Permata meminta fatwa MA atas permintaan Kejaksaan Negeri Jakarta Selatan.

37. 19 Juni 2003 BPPN minta fatwa MA dan penundaan eksekusi putusan MA yang membebaskan Joko S. Tjandra. Alasannya, ada dua putusan MA yang bertentangan.

38. 25 Juni 2003 Fatwa MA untuk direksi Bank Permata keluar. Isinya, MA tidak dapat ikut campur atas eksekusi.

Kata kejahatan dan tindak pidana sering di identikan, namun tindak pidana pengertiannya lebih luas dari pada kejahatan. Dalam kamus besar bahasa Indonesia Indonesia kata kejahatan diartikan sebagai perilaku yang bertentangan dengan nilai-nilai dan norma yang berlaku yang telah disahkan oleh hukum tertulis (hukum pidana). Tetapi jika disikmak dengan cermat, maka arti kata "kejahatan" yang paling tepat adalah yang dimuat dalam The Lexicon Webster Dictonary, jika diterjemahkan (secara bebas) maka pengertian kejahatan adalan suatu perbuatan aktif atau pasif, terutama yang sifatnya seram 
(menakutkan) yang dikenai sanksi berdasarkan hukum sebagai pelanggaran terhadap statute (undang-undang), atau membahayakan keselamatan / kesejahtraan umum. ${ }^{5}$

Menurut Munir Fu'ady yang dimaksud dengan tindak pidana perbankan adalah suatu jenis perbuatan yang secara melawan hukum dilakukan, baik dengan sengaja ataupun dengan tidak sengaja yang ada hubungannya dengan lembaga, perangkat dan produk perbankan, sehingga menimbulkan keruguian metriil dan atau immateriil bagi perbankan itu sendiri maupun bagi nasabah atau pihak ketiga lainnya. ${ }^{6}$ Sedangkan yang dimaksud dengan kejahatan perbankan adalah segala kegiatan perbankan yang diatur secara yuridis dalam UU No. 10 Tahun 1998 serta termasuk menjalankan prinsip-prinsip perbankan (prudent banking) dengan cara menggunakan rambu-rambu hukum berupa safe dan sound. Kegiatan bank harus safe maksudnya, kegiatan bersangkutan tidak boleh membawa resiko yang substansial (substantive risko) kepada bank. Kegiatan bank harus sound maksudnya adalah kegiatan bank tersebut harus layak digolongkan sebagai kegiatan suatu bank, termasuk kegiatan bank secara yuridis dan secara umum antara lain ${ }^{7}$ :

1. Penarikan dana masyarakat,

2. Penyaluran dana kepada masyarakat,

3. Kegiatan fee based, dan

4. Kegiatan dalam bentuk investasi.

Perbedaan antara tindak pidana perbankan dengan tindak pidana di bidang perbankan, perbedaanya terdapat pada perlakuan peraturan terhadap perbuatan yang telah melanggar hukum yang berkaitan dengan usaha menjalankan industri perbankan, perlakuan tersebut dapat kita lihat pada ${ }^{8}$ :

1. Tindak pidana perbankan terdiri dari perbuatan-perbuatan pelanggaran terhadap ketentuan UU No. 14 Tahun 1967 Tentang Pokok-Pokok Perbankan. Pelanggaran mana dilarang dan diancam dengan hukuman oleh UU ini.

2. Tindak pidana di bidang perbankan lainnya yang terdiri atas perbuatan-perbuatan yang berhubungan dengan kegiatan dalam menjalankan usaha pokok bank, terhadap perbuatan mana dapat diperlakukan peraturan-peraturan pidana di luar UU No. 14 Tahun1967, seperti :

\footnotetext{
${ }^{5}$ Leden Marpaung, Pemberantasan dan Pencegahan Tindak Pidana terhadap Perbankan, Cetakan ke 2, Djambatan, Jakarta, 2005, hlm 4

${ }^{6}$ Munir Fuady, Bisnis Kotor, Anatomi Kejahatan Kerah Putih, Citra Aditia Bhakti, Bandung, 2004, hlm 74.

${ }^{7}$ A.M. Mujahidin, Reevalluasi dan reorientasi penagananTindak kejahatan Perbankan, Mengurai Benang Kusut Penyalah gunaan BLBI,www. Hukumonline.com, diakses pada tanggal 14 April 2017

${ }^{8}$ A.M. Mujahidin, Ibid
} 
a. KUHP sebagai peraturan hukum pidana.

b. Peraturan-peraturan hukum pidana khusus, seperti UU No. 3 Tahun $1977^{9}$ tentang tindak pidana korupsi, UU No. 32 Tahun $1964^{10}$ tentang Lalulintas Devisa.

c. Peraturan-peraturan lain yang berhubugan dengan kegiatan bank dan yang memuat ketentuan pidananya. ${ }^{11}$

Eksistensi, karakteristik, bentuk dan jenis perumusan tindak pidana di bidang perbankan tidak hanya terbatas pada perumus dan dalam UU No. 7 Tahun 1992yang telah diubah dengan UU No. 10 Tahun 1998 tentang Perbankan, melainkan juga mencakup tindak pidana lainnya yang diatur dan tersebar di luar UU Perbankan yang ada relevansinya dengan kegiatan perbankan, seperti dalam UU No. 23 Tahun 1999 Tentang Bank Indonesia, UU No. 24 Tahun1999 Tentang Lalulintas Devisa dan Sistem Nilai Tukar, UU No. 31 Tahun 1999 yang telah diubah dengan UU No. 20 Tahun2001 Tentang Pemberantasan Tindak Pidana Korupsi.

Walaupun kejahatan perbankan dikatakan sebagai tindak pidana ekonomi, namaun pada dasarnya perbankan sudah termasuk kejahatan di bidang perbankan. Hal ini dapat digolongkan menjadi tiga kategori yakni ${ }^{12}$ :

1. Kejahatan fisik, maksudnya adalah kejahatan perbankan yang melibatkan fisik dan merupakan kejahatan yang konvensional serta berhubungan dengan perbankan, contohnya perampokan bank, penipuan dan lain-lain.

2. Kejahatan Pelanggaran Administrasi perbankan, maksudnya adalah bank sebagai lembaga pelayanan publik, maka banyak ketentuan administrasi dibebankan oleh hukum kepadanya, bahkan pelanggaran beberapa ketentuan administrasi dianggap oleh hukum sebagai tindak pidana, hal ini terdapat dalam :

a. Operasi bank tanpa ijin.

b. Tidak memenuhi pelaporan kepada Bank Sentral.

\footnotetext{
${ }^{9}$ Lihat, UU No. 3 tahun 1971 sekarang diganti dengan UU No. 31 Tahun 1999 jo UU No. 20 Tahun 2001.

${ }^{10}$ lihat UU No. 32 Tahun 1964 telah dihapus dan diganti dengan UU No. 24 Tahun 1999 Tentang Lalulintas Devisa dan Sistem Nilai Tukar Uang

${ }^{11}$ Ismansah, "Sistem Penyelidikan, Penyidikan dan Penuntutan Kejahatan di Bidang Perbangkan (Studi Penangan Kasus Penyalahgubnaan BLBI Oleh Kejaksaan Agung)", Disertasi, PDIH UNDIP Semarang, 2007, hlm 1.

${ }^{12}$ Ismansah, ibid, hlm10
} 
c. Tidak memenuhi ketentuan Bank Sentral tentang kecukupan modal, batas maksimum pemberian kridit, persyaratan pengurus dan komisaris, merger, akuisisi serta konsolidasi bank dan lain-lain.

3. Kejahatan Produk bank, maksudnya adalah kejahatan perbankan yang dihubungkan dengan produk bank seperti, pemberian kridit yang tidak benar, misalnya kridit tanpa agunan atau agunan fiktif, pemalsuan warkat, seperti cek, wesel, dan leter of cridit, pemalsuan kartu kridit, transfer uang kepada yang tidak berhak.

Kejahatan perbankan yang disebut sebagai pelanggaran moralitas perbankan, sebagaimana tercantum dalam Kode Etik Bankir Indonesia, yang berisikan sebagai berikut:

a. Patuh dan taat pada ketentuan perundang-undangan dan peraturan-peraturan yang berlaku.

b. Melakukan pencatatan yang benar mengenai segala transaksi yang bertalian dengan kegiatan banknya.

c. Menghindarkan diri dari persaingan yang tidak sehat.

d. Tidak menyalahgunakan wewenangnya untuk kepentingan pribadi.

e. Menghindarkan diri dari keterlibatan pengambilan keputusan dalam hal terdapat pertentangan kepentingan.

f. Menjaga rahasia nasabah dan banknya.

g. Memperhatikan dampak yang merugikan dari setiap kebijakan yang ditetapkan bank terhadap keadaan ekonomi, sosial dan lingkungannya.

h. Tidak menerima hadiah atau imbalan yang memperkaya diri pribadi atau keluarga.

i. Tidak melakukan perbuatan tercela yang dapat merugikan citra profesinya ${ }^{13}$

Menurut Mardjono Reksodiputro, pelanggaran kode etik secara yuridis tidak dapat dikategorikan sebagai tindak pidana (crime), tetapi secara kriminologis dapat diketegorikan dalam pengertian criminal behavior dalam konsepsi white collar crime. ${ }^{14}$ Sementara menurut Krisna Wijaya, kejahatan perbankan dilihat dari berbagai kasus

\footnotetext{
${ }^{13}$ Munir Fuadi, op. cit., hlm 3.
}

${ }^{14}$ Ismansah, op.cit., hlm 10 
Pembobolan bank disebabkan oleh kalangan intern bank dan bentuk kontrol kejahatannya terdapat dalam dua jenis kejahatan perbankan, yaitu: ${ }^{15}$

a. Error Omission berupa pelanggaran terhadap suatu ketentuan berupa sistem dan prosedur yang seharusnya dipatuhi tetapi tidak dilaksanakan.

b. Error Commision berupa pelanggaran dalam bentuk melaksanakan sesuai yang seharusnya tidak boleh, karena tidak tertulis dalam sistem dan prosedur, maka tetap saja dilakukan.

Pelanggaran terhadap error omission selalu ada sanksi administratif, tetapi pelanggaran terhadap error commission sanksinya bersifat normatif yang terdapat dalam code of conduct, dan kebanyakan kejahatan perbankan di Indonesia terdapat dalam bentuk error commission khususnya dalam delivery system ${ }^{16}$. Secara umum kejahatan di bidang perbankan adalah kejahatan yang digolongkan dalam peraturan perundang-undangan di bidang hukum admnistrasi yang memuat sanksi-sanksi pidana. Istilah kejahatan di bidang perbankan adalah untuk menampung segala jenis perbuatan melanggar hukum yang berhubungan dengan kegiatan-kegiatan dalam menjalankan usaha bank. Sedangkan istilah tindak pidana di bidang perbankan menunjukkan bahwa suatu tindak pidana yang dilakukan dalam menjalankan fungsi dan usahanya sebagai bank dan dapat dikategorikan sebagai tindak pidanan ekonomi. Kejahatan di bidang perbankan adalah salah satu bentuk dari kejahatan ekonomi yang sering dilakukan dengan menggunakan bank sebagai sasaran dan sarana kegiatannya dengan modus yang sangat sulit dipantau atau dibuktikan berdasarkan undang-undang perbankan. ${ }^{17}$

Modus operansi kejahatan di bidang perbankan dilakukan melalui memperoleh kredit dari bank dengan cara menggunakan dokumen atau jaminan palsu, fiktif, penyalahgunaan pemakaian kredit, mendapat kredit berulang-ulang dengan jaminan objek yang sama, memerintahkan, menghilangkan, menghapuskan, tidak membukukan yang seharusnya dipenuhi. Di samping itu modus operandinya juga memaksa bank atau pihak yang terafeliasi memberikan keterangan yang wajib dirahasiakan, tidak memberikan keterangan yang wajib dipenuhinya kepada bank Indonesia maupun kepada Penyidik Negara, menerima, meminta, mengijinkan, menyetujui untuk menerima imbalan, uang

\footnotetext{
${ }^{15}$ Krisna Wijaya, Analisis Krisis Perbankan Nasional, catatan kolom demi kolom, Penerbit Kompas, Jakarta, 2000, hlm. 38.

${ }^{16}$ Krisna Wijaya, Ibid. hlm 39.

${ }^{17}$ A.M. Mujahidin, Loc.it
} 
tambahan, pelayanan komisi, uang atau barang berharga untuk kepentingan pribadi dalam rangka orang lain mendapat kridit, uang muka, prioritas kredit atau persetujuan orang lain untuk melanggar batas maksimum pemberian kredit $(\mathrm{BMKP})^{18}$.

Bahwa perbuatan yang dilakukan oleh Bank Bali pada tanggal 21 Oktober 1998 perihal tidak terbayarnya tagihan piutang di BDNI dan BUN yang timbul dari transaksi money market, SWAP, dan pembelian promissory notes. Tagihan pada BDNI (belum dihitung bunga) Rp 428,25 miliar dan US\$ 45 juta. Sedangkan tagihan ke BUN senilai Rp 200 miliar. Menurut ketentuan Pasal 12 ayat (3) Peratuaran Bank Indonesia NO. 7/2PBI/2005 tentang penilaian Kualitas Aktiva Bank Umum, kualitas kredit terbagi menjadi lima kolektilibilitas, yaitu: Lancar, Dalam perhatian Khusus, Kurang Lancar, Diragukan, dan Macet. Perbutan yang dilakukan Bank Bali tersebut termasuk dalam katagori kredit macet dimana terdapat tungakan angsuran pokok dan/atau bunga sebesar Rp 428,25 miliar (belum di hutung bunga) dan US\$ 45 juta kepada BDNI,sedangkan tagihan ke BUN senilai Rp 200 miliar yang telah melampaui 270 (dua ratus tujuh puluh) hari., kerugian operasional ditutup dengan pinjaman baru, dan segi hukum maupun kondisi pasar, jsminan tidak dapat dicairakan pada nilai wajar. ${ }^{19}$ Perbutan kredit macet ini termasuk kedalam kejahatan perbankan karena tentang kredit diatur Undang-Undang No. 7 Tahun 1992 tentang Perbankan sebagiaman Telah diubah dengan Undang-Undang No. 10 Tahun 1998. Menurut Munir Fu'ady yang dimaksud dengan tindak pidana perbankan adalah suatu jenis perbuatan yang secara melawan hukum dilakukan, baik dengan sengaja ataupun dengan tidak sengaja yang ada hubungannya dengan lembaga, perangkat dan produk perbankan, sehingga menimbulkan keruguian metriil dan atau immateriil bagi perbankan itu sendiri maupun bagi nasabah atau pihak ketiga lainnya ${ }^{20}$ Tindak Pidana Perbankan \& Tindak Pidana di Bid. Perbankan Merupakan Tindak Tidana Ekonomi. Unsur-unsur Tindak Pidana Ekonomi

Menurut Conklin:

1. Suatu perbuatan melawan hukum yang diancam dengan sanksi pidana

2. Dilakukan oleh perorangan atau korporasi di dalam pekerjaannya yang sah atau dalam usahanya di bidang industri atau perdagangan.

3. Tujuan : memperoleh uang, kekayaan, menghindari pembayaran uang/ menghindari kekayaan/kerugian/keuntungan bisnis atau keuntungan pribadi

\footnotetext{
${ }^{18}$ A.M. Mujahidin, ibid

${ }^{19}$ Hermansyah, Hukum Perbankan Nasional Indonesia, Prenada Media Group Jakarta,2006, hlm 67

${ }^{20}$ Munir Fuady, loc it
} 


\subsection{Analisis Peran Bank Indonesia Dalam Kejahatan Perbankan Yang Dilakukan Oleh Bank Bali}

Bank Sentral merupakan lembaga yang memiliki peran penting dalam perekonomian, terutama di bidang moneter, keuangan dan perbankan. Peran tersebut tercermin pada tugas-tugas utama yang dimiliki oleh Bank Sentral, yaitu menetapkan dan melaksanakan kebijakan moneter, mengatur dan mengawasi bank,serta menjaga kelancaran sistem pembayaran. Tugas utama tersebut tidak selalu sama antara satu bank sentral dengan bank sentral lainnya. Misalnya, terdapat bank sentral yang hanya bertugas menetapkan dan melaksanakan kebijakan moneter serta menjaga kelancaran sistem pembayaran, sementara terdapat juga bank sentral lain yang hanya bertugas menetapkan dan melaksanakan kebijakan moneter. Tugas utama yang pada umumnya dimiliki oleh bank sentral tersebut, juga dimiliki oleh Bank Indonesia selaku bank sentral Republik Indonesia. $^{21}$

Keberadaan bank sentral juga diperlukan untuk mengatur dan mengawasi perbankan agar aktifitasnya dapat berkembang sehat dan berjalan lancar sehingga dapat mendorong kegiatan ekonomi. Hal itu mengingat bahwa keberadaan regulator yang tidak berpihak akan membawa bank-bank dapat melaksanakan operasinya secara effisien dan mampu memajukan perkembangan perekonomian. Contohnya, kalau tidak ada regulator, maka kepentingan para deposan akan kurang mendapat perhatian, dan juga akan dapat muncul praktek-praktek yang merugikan kepentingan nasabah suatu bank. Demikian pula, bank-bank kecil dapat mengalami kesulitan karena belum tentu mampu bersaing dengan bank-bank yang lebih besar dan kuat. Selain sebagai regulator, bank sentral juga diperlukan untuk berperan sebagai banker's bank dalam menjalankan fungsinya sebagai lender of last resort 'pemberi pinjaman terakhir' bagi bank-bank yang mengalami kesulitan pendanaan jangka pendek (likuiditas) dan tidak dapat memperoleh pinjaman dari bank lain. ${ }^{22}$

Dengan berekembangnya peran seperti diuraikan di atas, bank sentral tidak lagi identik dengan bank komersial atau lembaga keuangan lainnya. Masyarakat umum tidak dapat lagi menyimpan uangnya atau meminta kredit atau mentransfer uang di bank sentral. Bank sentral dibentuk sebagai regulator dan pembuat kebijakan untuk mencapai

\footnotetext{
${ }^{21}$ Neni Sri Imaniati, Dasar-Dasar Hukum Perbankan dan Perbankan syariah, Fakultas Hkum UNISBA, Bandung, 2007, hlm 68

${ }^{22}$ Neni Sri Imaniati,Ibid, hlm 71
} 
suatu tujuan sosial ekonomi tertentu yang menyangkut kepentingan nasional atau kesejahteraan umum, seperti stabilitas harga dan perkembangan ekonomi. Dalam perkembangan selanjutnya, untuk dapat melaksanakan perannya, bank sentral mempunyai beberapa kewenangan antara lain : ${ }^{23}$

1). Mengedarkan uang sekaligus mengatur jumlah uang beredar,

2). Mengatur dan mengawasi kegiatan perbankan,

3). Mengembangkan sistem pembayaran, dan

4). Mengembangkan sistem perkreditan

Dalam sistem pembayaran antar bank, Bank Indonesia memiliki tugas untuk mengatur dan menjaga kelancaran sistem pembayaran. Permasalahan yang terjadi pada kasus Bank Bali, tugas Bank Indonesia sebagai lembaga yang mengatur dan menjaga kelancaran sistem pembayaran antara BDNI dan Bank Bali, hal tersebut terlihat dari mekanisme antara BPPN dan Bank Indonesia dimana pada saat terjadi penyelesaian utangpiutang antara Bank Bali dan BDNI, Bank Bali mengirim surat ke BDNI untuk minta konfirmasi soal utang-utang yang jatuh tempo pada 2 Maret 1998 sampai 16 Maret 1998 (6 transaksi) dan mengirim surat surat ke BPPN perihal tidak terbayarnya tagihan piutang di BDNI dan BUN yang timbul dari transaksi money market, SWAP, dan pembelian promissory notes. Tagihan pada BDNI (belum dihitung bunga) Rp 428,25 miliar dan US\$ 45 juta. Sedangkan tagihan ke BUN senilai Rp 200 miliar.BPPN meminta bantuan BI untuk melakukan verifikasi atas tagihan Bank Bali ke BDNI dan BUN dari segi kewajaran dan kebenarannya.

Hasil dari verifikasi terhadap tagihan-tagihan Bank Bali ke BDNI dan BUN, antara lain: tidak ditemukan indikasi ketidakbenaran dan ketidakwajaran transaksi SWAP, forward dan L/C antara Bank Bali dengan BDNI, transaksi pembelian promes yang diendorse BUN belum sesuai dengan prinsip praktek perbankan yang berhati-hat (prudential bankin).

\section{PENUTUP}

\subsection{Simpulan}

Bahwa perbuatan yang dilakukan oleh Bank Bali pada tanggal 21 Oktober 1998 perihal tidak terbayarnya tagihan piutang di BDNI dan BUN yang timbul dari transaksi money market, SWAP, dan pembelian promissory notes. Tagihan pada BDNI (belum

${ }^{23}$ Neni Sri Imaniati,Ibid, hlm 72 
dihitung bunga) Rp 428,25 miliar dan US\$ 45 juta. Sedangkan tagihan ke BUN senilai Rp 200 miliar. Menurut ketentuan Pasal 12 ayat (3) Peratuaran Bank Indonesia NO. 7/2PBI/2005 tentang penilaian Kualitas Aktiva Bank Umum, kualitas kredit terbagi menjadi lima kolektilibilitas, yaitu: Lancar, Dalam perhatian Khusus, Kurang Lancar, Diragukan, dan Macet. Perbutan yang dilakukan Bank Bali tersebut termasuk dalam katagori kredit macet dimana terdapat tungakan angsuran pokok dan/atau bunga sebesar Rp 428,25 miliar (belum di hutung bunga) dan US\$ 45 juta kepada BDNI,sedangkan tagihan ke BUN senilai Rp 200 miliar yang telah melampaui 270 (dua ratus tujuh puluh) hari., kerugian operasional ditutup dengan pinjaman baru, dan segi hukm maupun kondisi pasar, jsminan tidak dapat dicairakan pada nilai wajar. Perbutan kredit macet ini termasuk kedalam kejahatan perbankan karena tentang kredit diatur Undang-Undang No. 7 Tahun 1992 tentang Perbankan sebagiamana telah diubah dengan Undang-Undang No. 10 Tahun 1998. Hasil dari verifikasi terhadap tagihan-tagihan Bank Bali ke BDNI dan BUN, antara lain: tidak ditemukan indikasi ketidakbenaran dan ketidakwajaran transaksi SWAP, forward dan L/C antara Bank Bali dengan BDNI, transaksi pembelian promes yang diendorse BUN belum sesuai dengan prinsip praktek perbankan yang berhati-hati.

\subsection{Saran}

Peranan bank sentral harus lebih proaktif untuk mengatur dan mengawasi perbankan agar aktifitasnya dapat berkembang sehat dan berjalan lancar sehingga dapat mendorong kegiatan ekonomi. Hal itu mengingat bahwa keberadaan regulator yang tidak berpihak akan membawa bank-bank dapat melaksanakan operasinya secara effisien dan mampu memajukan perkembangan perekonomian

\section{DAFTAR PUSTAKA}

\section{Buku-Buku}

Emmy Yusaharie(ed), 2004, Perseroan Terbatas dan Good Corporate Governance, Rangkaian Lokakarya Membahas Masalah-Masalah Kepailitan dan Wawasan hukum Bisnis lainya, Jakarta.

Hermansyah, 2006, Hukum Perbankan Nasional Indonesia, Prenada Media Group, Jakarta.

Ismansah, 2007,"Sistem Penyelidikan, Penyidikan dan Penuntutan Kejahatan di Bidang Perbangkan (Studi Penangan Kasus Penyalahgubnaan BLBI Oleh Kejaksaan Agung) ", Disertasi, PDIH UNDIP Semarang 
Krisna Wijaya, 2000, Analisis Krisis Perbankan Nasional, catatan kolom demi kolom, Penerbit Kompas, Jakarta.

Leden Marpaung, 2005, Pemberantasan dan Pencegahan Tindak Pidana terhadap Perbankan, Cetakan ke 2, Djambatan, Jakarta.

Muhammahd Djumhana, 2006, Hukum Perbankan Indonesia, cet 5, PT Citra Aditya Bakti, Bandung.

Munir Fuady, 2004, Bisnis Kotor, Anatomi Kejahatan Kerah Putih, Citra Aditia Bhakti, Bandung.

Neni Sri Imaniati, 2007, Dasar-Dasar Hukum Perbankan dan Perbankan syariah, Fakultas Hukum UNISBA, Bandung, 2007

\section{Peraturan Perundang-undangan:}

Undang-undang nomor 3 Tahun 2004 tentang perubahan atas undang-undang nomor 23

Tahun 1999 tentang bank Indonesia

Undang-undang nomor 10 Tahun 1998 tentang perubahan atas undang-undang nomor 7 tahun 1992 tentang perbankan 